\title{
Article \\ Fire Parameters of Spruce (Picea abies Karst. (L.)) Dust Layer from Different Wood Technologies Slovak Case Study
}

\author{
Eva Mračková ${ }^{1}$, Jarmila Schmidtová ${ }^{2}$, Iveta Marková ${ }^{3, * \mathbb{D}}$, Jana Jad'ud'ová ${ }^{4}$, Ivana Tureková ${ }^{5}$ and Miloš Hitka \\ 1 Department of Fire Protection, Technical University in Zvolen, Masaryka 24, 96001 Zvolen, Slovakia; \\ mrackova@tuzvo.sk \\ 2 Department of Mathematics and Descriptive Geometry, Technical University in Zvolen, Masaryka 24, \\ 96001 Zvolen, Slovakia; schmidtova@tuzvo.sk \\ 3 Department of Fire Engineering, Faculty of Security Engineering, University of Žilina, Univerzitná 1, \\ 01026 Žilina, Slovakia \\ 4 Department of Environmental Management, Faculty of Natural Sciences, Matej Bel University in \\ Banská Bystrica, Tajovského 40, 97401 Banská Bystrica, Slovakia; jana.jadudova@umb.sk \\ 5 Department of Technics and Technology, Pedagogical Faculty, Constantine the Philosopher University \\ in Nitra, Tr. A. Hlinku 1, 94974 Nitra, Slovakia; turekova@ukf.sk \\ 6 Department of Economics, Management and Business, Technical University in Zvolen, Masaryka 24, \\ 96001 Zvolen, Slovakia; hitka@tuzvo.sk \\ * Correspondence: iveta.markova@fbi.uniza.sk; Tel.: +421-041-513-6679
}

check for updates

Citation: Mračková, E.; Schmidtová, J.; Marková, I.; Jad'ud'ová, J.; Tureková, I.; Hitka, M. Fire Parameters of Spruce (Picea abies Karst. (L.)) Dust Layer from Different Wood Technologies Slovak Case Study. Appl. Sci. 2022, 12, 548. https://doi.org/10.3390/ app12020548

Academic Editor: Stefano Invernizzi

Received: 5 November 2021 Accepted: 28 December 2021

Published: 6 January 2022

Publisher's Note: MDPI stays neutral with regard to jurisdictional claims in published maps and institutional affiliations.

Copyright: (c) 2022 by the authors. Licensee MDPI, Basel, Switzerland. This article is an open access article distributed under the terms and conditions of the Creative Commons Attribution (CC BY) license (https:// creativecommons.org/licenses/by/ $4.0 /)$.

\begin{abstract}
The issue of the formation of wood dust particles in the work environment is still an actual topic in terms of its impact on employee health and the risk of fire or explosion in a woodworking operation. This article deals with the characteristics of spruce dust (Picea abies Karst. (L.)), which was taken from several types of wood technology. Experimental samples of spruce dust were taken from four types of sawing technologies, including grinding, briquetting and from the suction device container. The physical parameters of the samples taken were monitored and the particle size analysis was determined. The granulometric composition of the samples is significantly different. The sample of spruce wood dust from sawing has the most numerous fraction $(250 \mu \mathrm{m})$, while the sample from grinding has the most numerous fraction $63-250 \mu \mathrm{m}(87 \%)$. The aim of the paper was to monitor the minimum ignition temperature of the settled spruce dust layer and to look for a significant dependence of the minimum ignition temperature and ignition time on the type of spruce dust sample. A significant dependence was not confirmed. Significant moisture dependence of the samples was confirmed; the highest humidity was observed in the container, the lowest in sawing.
\end{abstract}

Keywords: spruce dust; moisture; particle size analysis; minimum ignition temperatures of the deposited dust layer

\section{Introduction}

The existence of explosions is based on the presence of a substance that reacts with oxygen at low ignition sources. The wood industry is an example of an explosive environment. The permanent presence of wood dust particles in the atmosphere creates the risk of fire or explosion.

Dust is formed as a by-product of various processes, which include the transport of dry and powdered material, crushing and screening of solids, filling and storage of granular materials in tanks and reservoirs [1-3]. Wood and wood-based wastes are also subject to the processes of reducing the size of the wood, e.g., chipping, etc. In the woodworking industry, the processes of sawing, planning, milling, grinding, trimming and other processing of wood mass or wood-based materials are applied Sydor et al. [4]. Kaczmarzyk et al. [5] describe the impact of machines on the risk of fire. Wood machines are most often driven by internal combustion engines, whose selected components are characterized by high temperatures, and this is associated with the danger of a machine or environment fire [5]. 
Production residues are also subject to processes related to the reduction of the size of the wood, contributing to the formation of undesirable dust fractions [6]. The generation of dust during the handling and processing of materials can pose a risk to employees. This risk lies in the inhalation of the dust produced [7-11]. Wood dust poses a significant fire hazard, whether turbulent or settled [12-14].After ignition, the deposited dust may start to burn in the form of decay, incandescence and flame combustion [15-17]. When the available surface is greater, the process accelerates rapidly, increasing the emissions $[18,19]$.

Dust occurs in the environment in a wide range of particle sizes [20-22]. The particle size depends on the method of wood processing and its handling [23].

Particle size is one of the most important parameters of dust. Particle size measurement is commonly performed in various industries. Particle size is a critical parameter in production because it has a direct effect on the properties of the material or product, including reactivity [24-27]. Wood dust is a set of several particles of different sizes and shapes [28-30], which is evaluated granulometrically [31,32]. The fire-technical characteristics of an explosion is a set of parameters that includes [33]: upper and lower explosion limit, maximum explosion pressure, pressure rise rate, explosion constant, minimum ignition energy, ignition temperature of settled dust, ignition temperature of agitated dust, determination of susceptibility to spontaneous combustion and oxygen content limit. Distributions of combustible dusts in factories involved in dust explosions are described in detail in Zhi [34], with a dust explosion safety assessment.

Monitoring the behavior of wood dust in terms of its ignition is carried out by determining the minimum ignition temperature of dust [35-37]. The ignition temperature of settled dust $-t_{u M I N}-$ is the temperature that can be defined as the surface temperature at which spontaneous ignition of settled dust occurs [33].The $t_{u M I N}$ temperature is used to determine the lowest hot surface temperature in equipment $\left(t_{P R A C}\right)$ that can supply enough ignition energy to ignite the settled dust that comes into direct contact with this hot surface [38,39].

Tureková [40] formulates the dependence of the danger of ignition of a settled dust layer according to Damec [41] at the hot surface temperature $t_{P R A C}\left({ }^{\circ} \mathrm{C}\right)$ by the Equation (1):

$$
t_{P R A C} \geq k_{b} \times t_{u M I N}
$$

where:

$t_{P R A C}$ - hot surface temperature in ${ }^{\circ} \mathrm{C}$,

$t_{u M I N}$ - the minimum ignition temperature of settled dust,

$k_{b}$-a safety factor of $2 / 3$.

One of the key measures is to control the temperature of hot surfaces in a closed work environment.

Norway spruce Picea abies Karst. (L.) is the most frequently processed wood among all conifers, used for its good physical and mechanical properties [42] in Slovakia. At the same time, spruce is one of the most damaged woods due to climate change, which is important for its further intensive processing [43,44]. Norway spruce (Picea abies Karst. (L.)) is a coniferous tree; these trees have a simple microscopic structure because they are older in development than deciduous wood [45].

The object of the research is spruce wood dust, which is a waste product of the processing of common spruce in a wood processing plant. At the same time, carving experts consider spruce to be weak compared to other woody plants in terms of the impact of wood dust on the human body [46].The technological process of obtaining samples was performed using technological equipment from the largest processor of softwood in Slovakia ( $85 \%$ of spruce from the total production) [47]. The collected wood dust comes from various technological places. The individual processing of wood material is based on the principle of a line with pre-set parameters for the creation of the product, namely:

1. Wood sawing line: also called a sawmill (Figure 1a) with designation;

2. Grinding line, which consists of a line for grinding glued parts; 
3. Briquette production line (Figure $1 b)$.

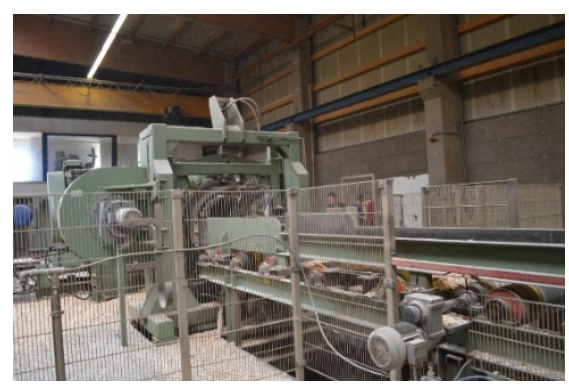

(a)

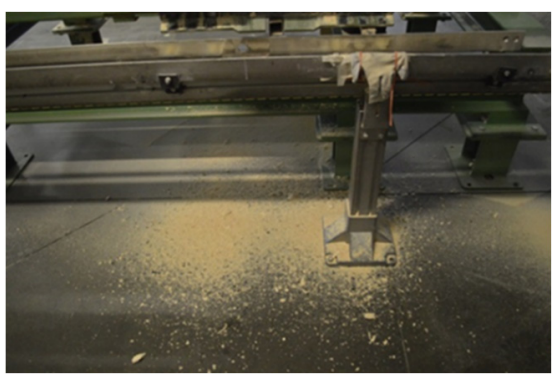

(b)

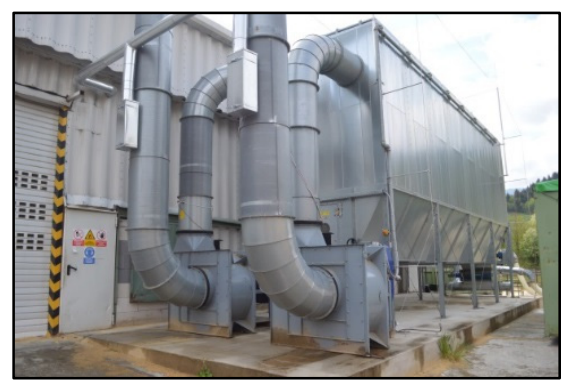

(c)

Figure 1. Samples of the sampling point. (a) Wood sawing line; (b) Briquette production line; (c) Extraction device.

An extraction device for extracting wood dust is secured by a filter device (filter NFKZ3000 7+1 HJ). Extraction of waste generated during the surface treatment of parts (from grinders and profiling cutters) is ensured by complete extraction from machines. The filter station with sawdust tank is located outside the hall building (Figure 1c).

The aim of this paper is to monitor the ignition of spruce dust samples from selected technologies. Attention is focused on monitoring the behavior of settled dust on a hot surface. The monitored parameter was the minimum ignition temperature of settled dust $t_{u M I N}$. A significant dependence of the minimum temperature and ignition time on the particle size distribution of the samples and the type of samples was sought.

Furthermore, the aim of the paper is to identify the particle size distribution of spruce wood dust by sieve analysis, on samples taken from various wood processing plants, and to look for a significant dependence of ignition on moisture and particle size ratio with respect to their technological preparation (sawing, briquetting, grinding and extraction equipment).

\section{Materials and Methods}

\subsection{Materials}

The sample is a part of the whole obtained by sampling, and represents the whole qualitatively and quantitatively [48]. Sampling reduced the original amount of the substance by selecting a proportion of it but did not change the composition ratio of the sample taken to the ratio of starting material. The methodical procedure of the preparation of representative samples is presented in Table 1.

The sample from a dust filter is called extraction device (WD_ExtrD) in the further analysis. This sample was obtained from a central extraction device and thus represents summary of particle sizes produced by different processes, offering a produced dust mixture.

\subsection{Determination of Physical Parameters of Dusts}

Moisture is the first parameter in relation to which wood samples were evaluated in compact form and dust form, and in terms of dependence on another characteristic wood matter [49]. The moisture's determination was performed on a METTLER TOLEDO HS153 instrument according to EN ISO 1666: 2000 [50]. Drying was performed fully automatically and at a temperature of $100{ }^{\circ} \mathrm{C}$, repeated 5 times.

The analytical sieving machine AS 200 basic with a sample weight of $25 \mathrm{~g}$ was used for sieve analysis. Each sample had a certain number of sieves with different hole sizes selected (Table 2). The device was set to an oscillation frequency of 75 and the screening took place for $15 \mathrm{~min}$. At the end of the sieving time, the sieves were automatically switched off and the fractions in the individual sieves were weighed. The procedure was repeated 5 times. Results were evaluated by ISO 9276-1 [51]. 
Table 1. Summary of the methodical procedure of spruce wood dust experiments.

\begin{tabular}{|c|c|}
\hline Methodical Step & Realization \\
\hline Examined object & spruce wood dust \\
\hline Sampling points & saw line \\
\hline & briquetting line \\
\hline & container, storage of waste from the suction pipe \\
\hline Time & one-time collection \\
\hline Partial sample collection & static \\
\hline Site selection & random (representative) collection \\
\hline Sampling procedure & $\begin{array}{l}\text { sampling was performed in the presence of an } \\
\text { employee and each sample taken from under the lines, } \\
\text { machinery and container was placed separately in the } \\
\text { package and labeled }\end{array}$ \\
\hline Amount of sample taken & $\begin{array}{c}\text { the sample was taken from each sampled portion } \\
\text { separately at } 10 \text { locations and } 10 \text { layers in the } \\
\text { suction container }\end{array}$ \\
\hline & $\begin{array}{l}\text { wood dust from the sawing line with designation as } \\
\text { WD_Saw }\end{array}$ \\
\hline & wood dust from the briquette line with designation as \\
\hline Experimental samples/designation & $\begin{array}{l}\text { WD_Briq } \\
\text { wood dust from the extraction device with designation }\end{array}$ \\
\hline & as WD_ExtrD \\
\hline & $\begin{array}{l}\text { wood dust from the grinding line with designation as } \\
\text { WD Grin }\end{array}$ \\
\hline Experiments & $\begin{array}{c}\text { determination of moisture } \\
\text { granulometric analysis, } \\
\text { determination of the minimum ignition temperature of } \\
\text { dust in a settled state }\end{array}$ \\
\hline
\end{tabular}

Table 2. Presented interface of used sieves to individual samples.

\begin{tabular}{|c|c|c|c|c|c|c|c|c|c|c|c|c|}
\hline \multirow{2}{*}{$\begin{array}{c}\text { Spruce } \\
\text { Dust }\end{array}$} & \multicolumn{12}{|c|}{ Fractions (Size $\mu \mathrm{m}$ ) } \\
\hline & 250 & 180 & 150 & 125 & 106 & 90 & 75 & 63 & 45 & 40 & 32 & $<32$ \\
\hline \multicolumn{13}{|l|}{ WD_Saw } \\
\hline \multicolumn{13}{|l|}{ WD_Grin } \\
\hline \multicolumn{13}{|l|}{ WD_Briq } \\
\hline WD_ExtrD & & & & & & & & & & & & \\
\hline
\end{tabular}

\subsection{Determination of the Minimum Ignition Temperature of Spruce Wood Dust in the Settled State}

The determination of the minimum ignition temperature of spruce wood dust in a settled state was carried out according to the methodological procedure EN 50281-2-1: 2002 [52].A "hot-plate" test device (in the Combustion Laboratory of the Faculty of Security Engineering of the Technical University of Žilina) for a deposited layer of dust (Figure 2) was used to measure the minimum ignition temperature.

The ignition source was an electrically heated surface of a circular metal plate (Figure 2b), which formed a working surface with a diameter of at least $200 \mathrm{~mm}$. The heated surface and its temperature control device met the following requirements:

- The heated surface must allow a maximum temperature of $400{ }^{\circ} \mathrm{C}$ (without a layer of dust);

- $\quad$ The temperature of the heated surface must be constant within $\pm 5{ }^{\circ} \mathrm{C}$ throughout the test;

- The steady state of the heated surface must have a uniform temperature distribution on the surface with a deviation of $\pm 5{ }^{\circ} \mathrm{C}$.

The recorded hot-plate surface temperature was maintained within 5 min of placing the dust layer. 


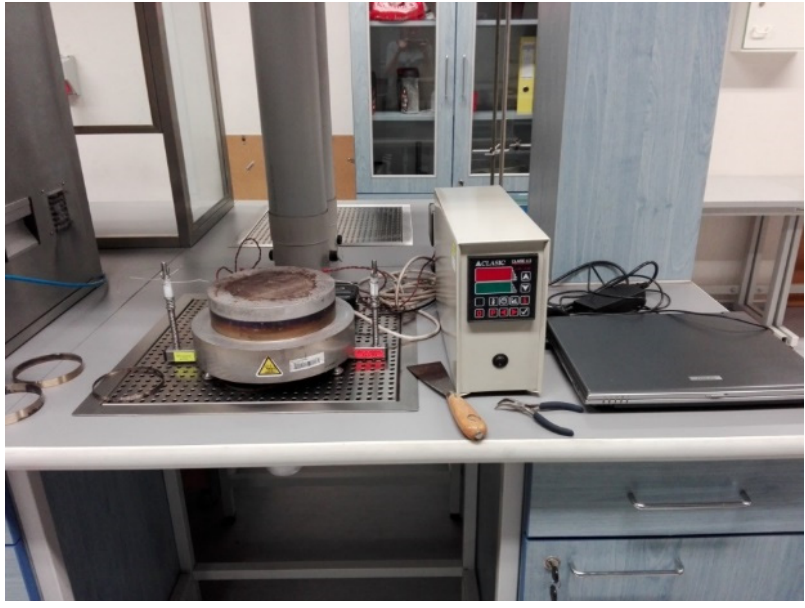

(a)

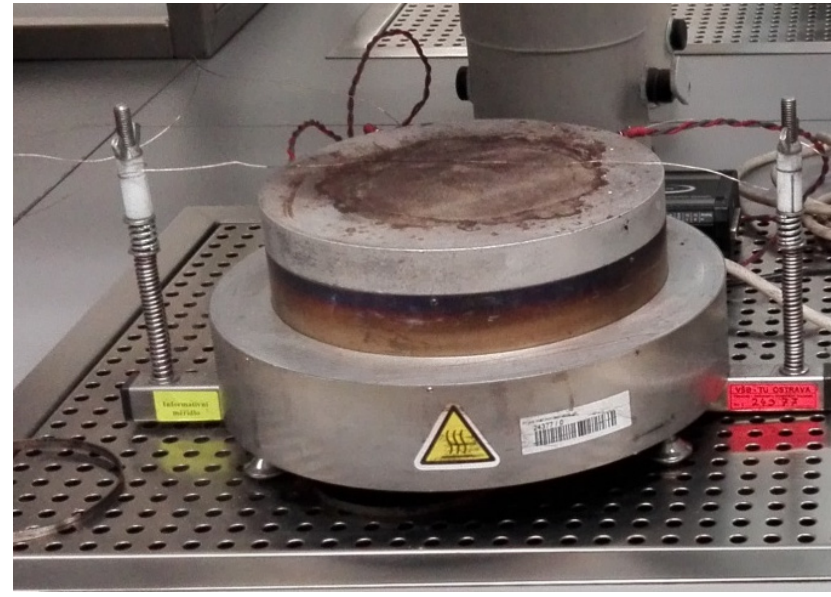

(b)

Figure 2. (a) Measuring apparatus; (b) hot-plate equipment by EN 50281-2-1: 2002 [53].

The measurement results were recorded by a thermocouple in a layer of dust located at a height of $2 \mathrm{~mm}$ to $3 \mathrm{~mm}$ above the surface of the dust layer.

The ambient temperature measured at a distance of up to $1 \mathrm{~m}$ from the heated surface was $(24.5 \pm 0.5){ }^{\circ} \mathrm{C}$, which met the requirements for the experiment. The dust layers were $5 \mathrm{~mm}$ thick. The ignition of a layer of dust on a surface at a given temperature depended significantly on the balance between the rate of heat generation (self-heating) in the layer and the rate of heat transfer to the surroundings. The ignition temperature of the material depended on the thickness of the layer [53]. According to EN 50281-2-1: 2002 [52], ignition is considered to be the case if:

1. Flames or glow are visible;

2. The measured temperature is $450{ }^{\circ} \mathrm{C}$;

3. The measured warming is $250{ }^{\circ} \mathrm{C}$ higher than the temperature of the heated plate.

Warguła et al. [54] presented the results of their research on high temperature impact $\left(400{ }^{\circ} \mathrm{C}\right)$ in the process of convection heat exchange on shredded plant material, including spruce, by the same standard method.

\section{Results and Discussion}

\subsection{Results of Determination of Physical Parameters of Spruce Wood Dust Samples}

By sieving the samples, the polydisperse system is completely divided into individual groups [55-58]. The resulting fractions contain particles with a size within certain limits given by the dimensions of the sieves used. A different mesh size interface was selected for each sample (Table 2). The color fields in Table 2 present the individual analyzed fractions of the samples, which are the existing fraction's size.

The saw sample (WD_Saw) was observed visually and contained the coarsest particles, causing sieves of larger dimensions to be selected (Figure 3). Wood dust from sawing had the largest share of the $250 \mu \mathrm{m}$ fraction at $69 \%$ (Table 3). The finest dust was produced by the grinder. Grinding, as a fine technological operation, produces adequate dimensions of dust particles (Table 3), corresponding to the expected size.

The results of the sieve analysis of spruce dust samples should be presented in accordance with the standard ISO 9276-1 [51]. Prepared Continuous Cumulative Curves are presented in Figure 3. 


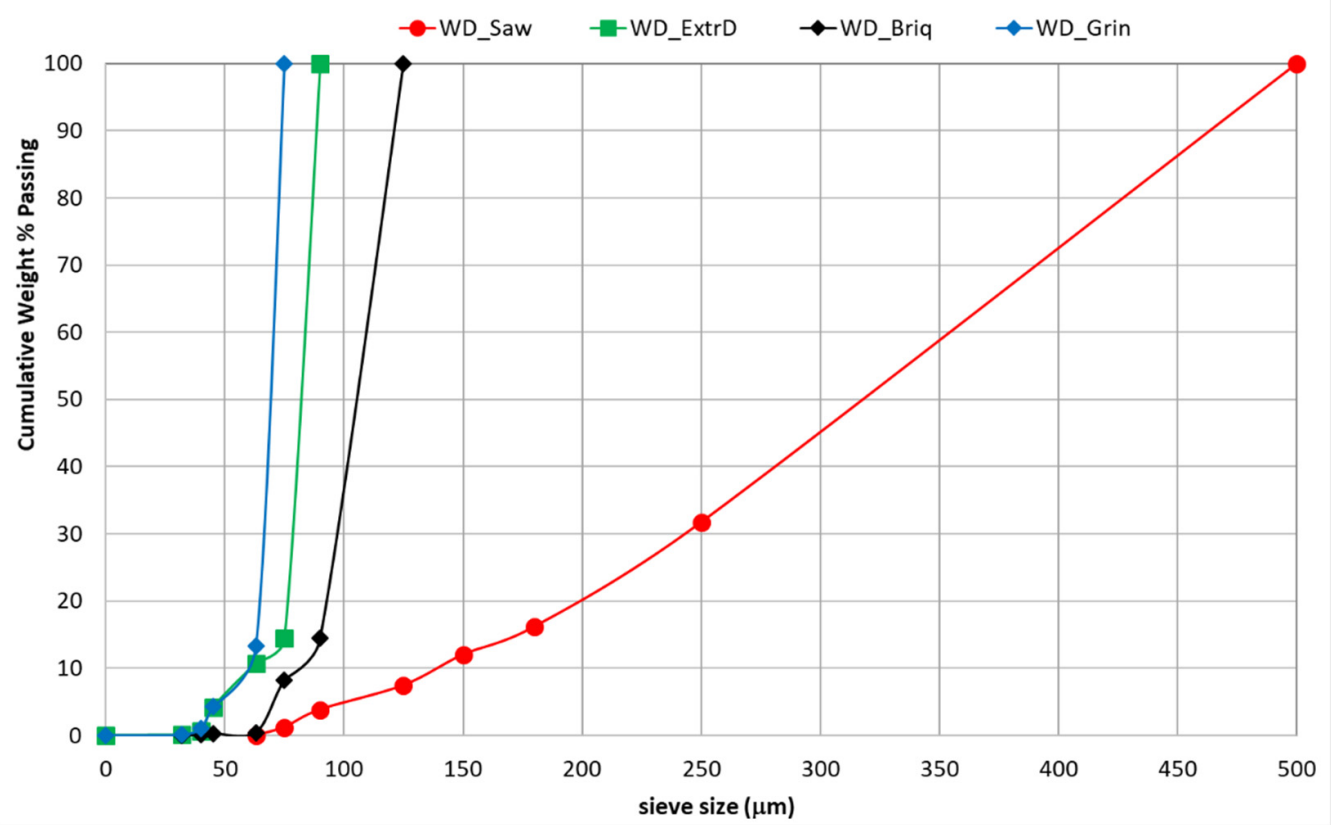

Figure 3. Continuous Cumulative Curve of spruce dust samples.

Table 3. Presentation of material parameters of spruce dust samples.

\begin{tabular}{ccccc}
\hline \multirow{2}{*}{ Parameters } & WD_Saw & WD_Briq & WD_ExtrD & WD_Grin \\
\cline { 2 - 5 } & $6.056 \pm 0.139$ & $7.248 \pm 0.480$ & $9.054 \pm 0.177$ & $8.42 \pm 0.403$ \\
\hline $\begin{array}{c}\text { Determination of wood } \\
\text { dust moisture (\%) } \\
\begin{array}{c}\text { Sieve analysis—average } \\
\text { value }(\mu \mathrm{m})\end{array}\end{array}$ & 250 & 106 & 75 & 63 \\
\hline
\end{tabular}

As part of the monitoring of the number of fractions in the dust sample from the suction device, a fraction of $75 \mu \mathrm{m}(85 \%)$ was found. The most numerous fraction of spruce wood dust from briquetting technology (WD_Briq) is $106 \mu \mathrm{m}$ (Table 3).

In Table 3, the largest grains contained the least moisture (\%), perhaps because they were newly cut and the relative humidity that day was low. The extracted dust (ExtrD) contained the most, perhaps because it has been stored in a filter for several days and attracted moisture from the atmosphere.

The results of the sieve analysis characterized dry spruce sawdust as a polydisperse bulk material with a grain size in the range of values from $85.38 \mu \mathrm{m}$ to $282 \mu \mathrm{m}$, and the most numerous representation in dry spruce sawdust were fractions with grain dimensions lying in the range of $d=125-1000 \mu \mathrm{m}$, making up $86.77-87.15 \%$ of the sawdust extracted from fine-cutting frame saws. The given results are also confirmed by Kučerka [59] for dry spruce and oak sawdust arising from wood sawing processes. Longauer and Dzurenda [60] performed an analysis of the shape, dimensions and particle size distribution of sawdust formed in the process of the longitudinal sawing of dry spruce lumber on fine-cutting frame saws of the type CLASIC 150/200 (at the material feed rate to the cut $v=0.5 \mathrm{~m} \cdot \mathrm{min}^{-1}$ ).

\subsection{Statistical Evaluation of the Obtained Results}

Statistical evaluation of the moisture comparison of samples taken from four types of sawing, briquette, container and grinding technologies was performed by a one-way analysis of variance and looked for a significant difference in the humidity of the samples (Table 4, Figure 4). 
Table 4. Analysis of variance of four wood dust samples with variable, moisture (\%).

\begin{tabular}{ccccccccc}
\hline & SC & SV & PČ & SC & SV & PČ & F & $p$ \\
\hline & effect & effect & effect & error & error & error & & \\
Moisture $^{*}(\%)$ & 26.29 & 3 & 8.76 & 2.23 & 16.00 & 0.14 & 63.02 & 0.000 \\
\hline
\end{tabular}

${ }^{*}$ Marked effects are significant at $p<0.05000$.

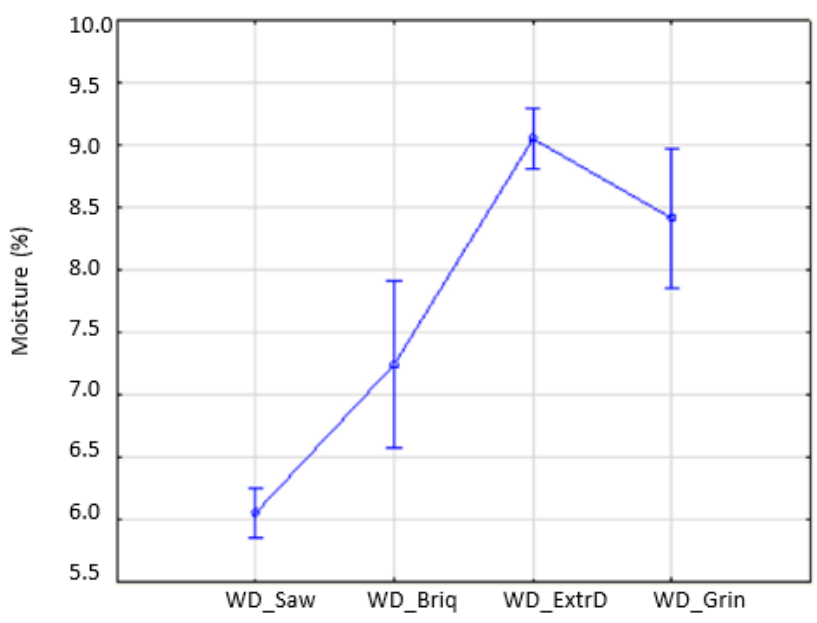

Figure 4. Graphical comparison of moisture level and variability of four different samples. Legend: " $\mathrm{x}$ " axis-dust samples.

At the level of significance $\alpha=5 \%$, we reject the 0 hypothesis about the equality of average humidity with different technologies. The moisture of the sawdust differs in a statistically significant way, and from the box graph in Figure 4 it is clear that the highest moisture was observed in the container, with the lowest observed in sawing.

One-factor analysis of variance was supplemented by Duncan's test, i.e., a simultaneous pairwise comparison, the results of which are presented in Table 5.

Table 5. Duncan test with variable, moisture (\%).

\begin{tabular}{ccccc}
\hline & $\{\mathbf{1}\}$ & $\{\mathbf{2}\}$ & $\{3\}$ & $\{4\}$ \\
\hline Moisture * (\%) & $\mathbf{M = 6 . 0 5 6 0}$ & $\mathbf{M}=\mathbf{7 . 2 4 8 0}$ & $\mathbf{M}=\mathbf{9 . 0 5 4 0}$ & $\mathbf{M = 8 . 4 2 0 0}$ \\
\hline sawing $\{1\}$ & & 0.000 & 0.000 & 0.000 \\
briquettes $\{2\}$ & 0.000 & & 0.000 & 0.000 \\
container $\{3\}$ & 0.000 & 0.000 & & 0.016 \\
grinder $\{4\}$ & 0.000 & 0.000 & 0.016 & \\
\hline
\end{tabular}

* Marked effects are significant at $p<0.05$.

Based on the results, we can state (Table 5) that there is a statistically significant difference in the moisture of the samples between all pairs of technologies.

Statistical evaluation of sieve analysis is difficult. Input values are different and variable values cannot be compared. It is possible to perform a mutual comparison of the percentage number of particle sizes from individual technological operations (Figure 5).

The clarity of the particle number shows the largest proportion of the saw sample. Said sample was not initiated in the hot-plate (Table 4). Sieve analysis represents the basic characteristics of wood dust, from which other parameters of the generated dust are derived, as evidenced by our result. The experimental results indicate a variability in the number of individual fractions depending on the wood dust formed. The statement is in accordance with other results, which we realized during the research on the wood dust of beech samples [13,61-66]. Kminiak et al. [67] have made statements regarding the course of the machining of spruce and following the making of dust fractions as ambiguous. 


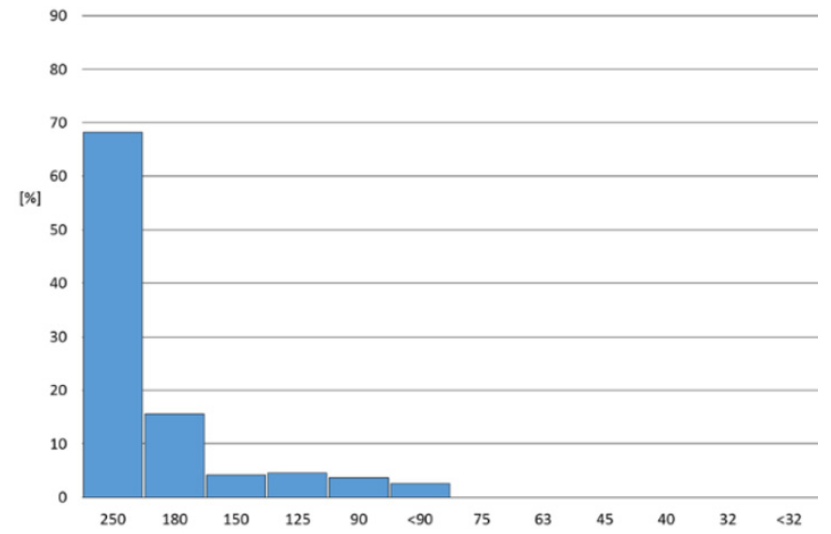

(a)

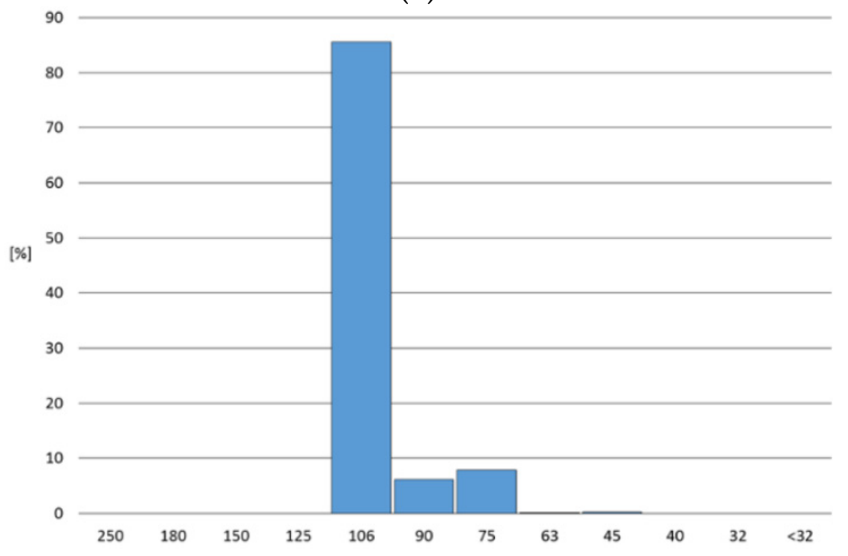

(c)

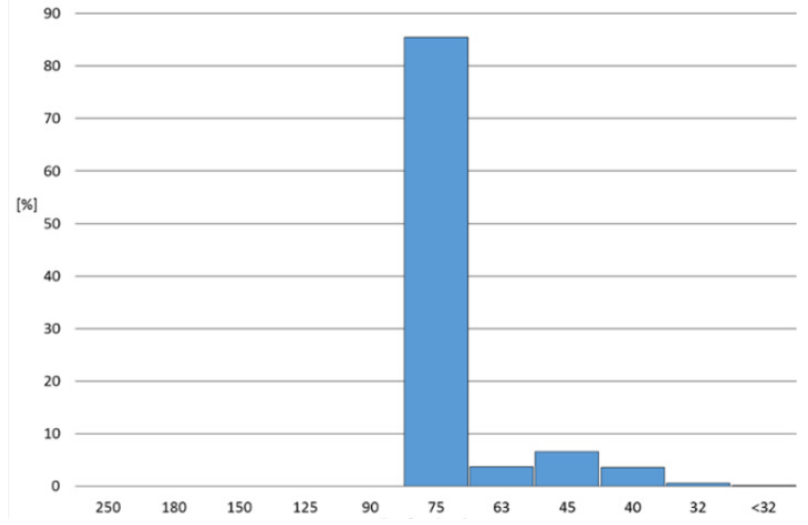

(b)

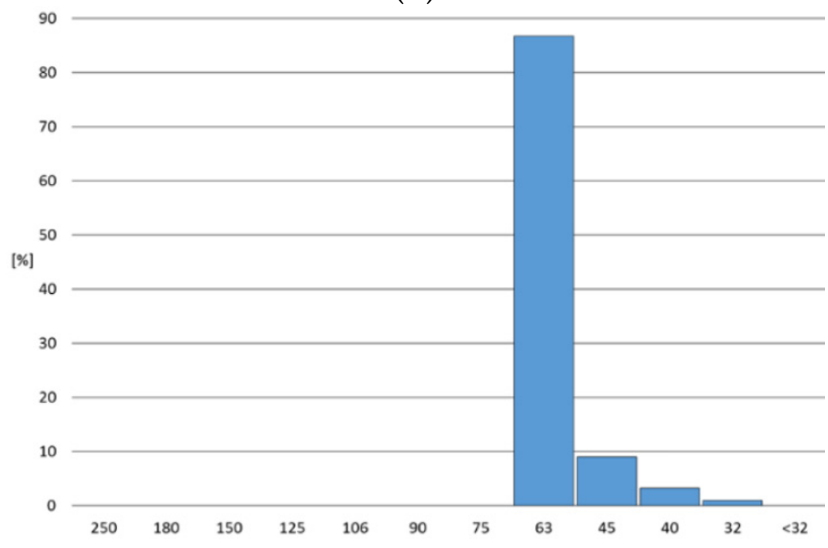

(d)

Figure 5. Presentation of the number of fractions of spruce wood dust samples. Legend: (a) WD_Saw; (b) WD_ExtrD; (c) WD_Briq; (d) WD_Grin.

\subsection{Ignition of Spruce Dust Samples by Hot Surface Ignition}

This set of experiments was preceded by indicative tests to determine the height of the spruce wood dust layer on the hot plate apparatus (Figure 6). The saw sample WD_Saw obtained from hot-plate sawing did not ignite. In the above experiments, no $5 \mathrm{~mm}$ layer of settled sawdust dust was initiated.

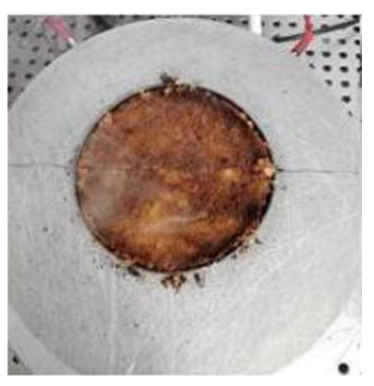

at $5^{\text {th }} \min$

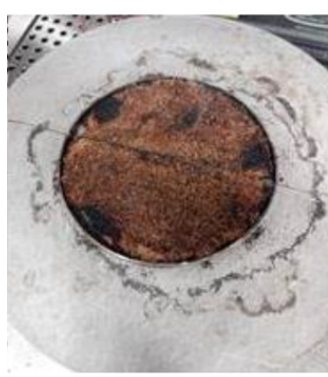

at $6^{\text {th }} \min$

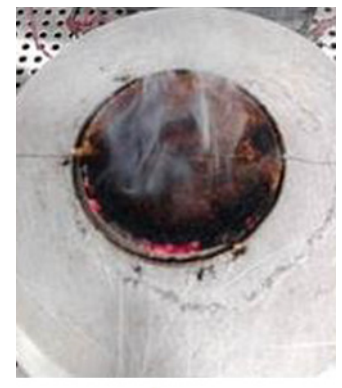

at $11^{\text {th }} \mathrm{min}$

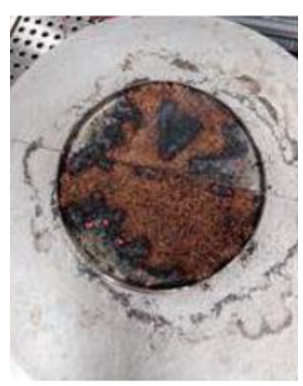

at $15^{\text {th }} \min$

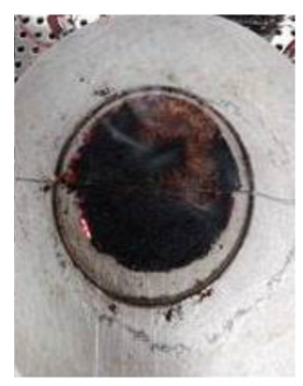

at $30^{\text {th }} \min$

Figure 6. Smoldering nests around the perimeter of the sample WD_ExtrD caused by the ignition source, i.e., a hot surface.

Spruce dust samples from briquetting (Figure 7a), suction (Figure 7b) and grinding (Figure 7c) were ignited. The obtained data were different (Table 6).Schemes followed the same formatting. 


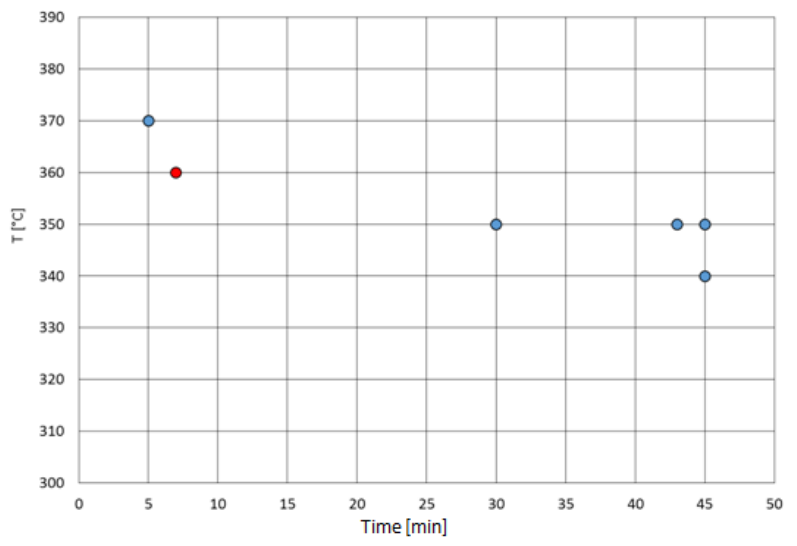

(a)

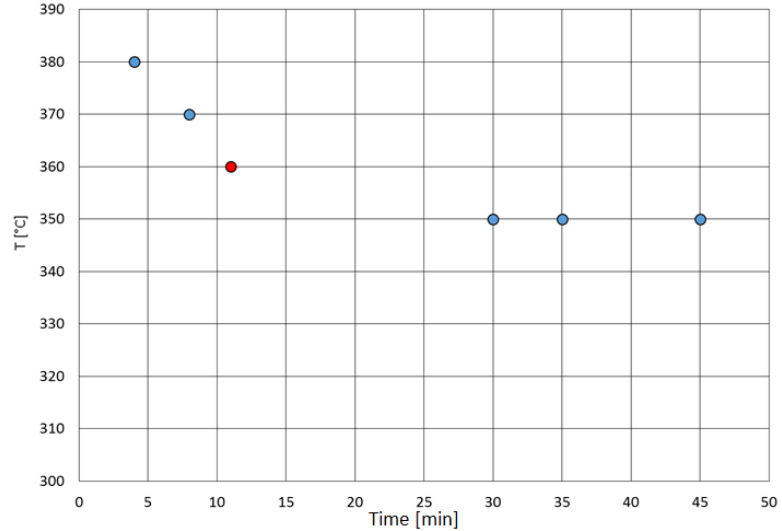

(b)

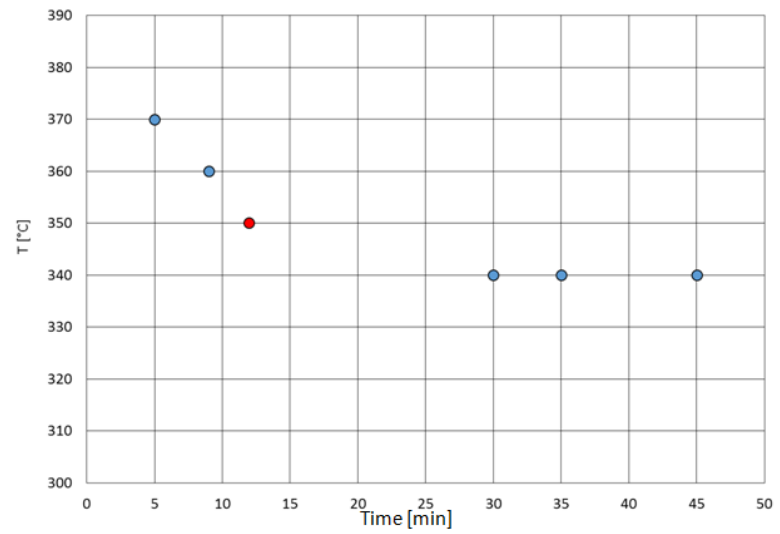

(c)

Figure 7. Determination of the ignition temperature of settled wood dust (a) from briquetting; (b) removed from the container; (c) removed from grinding.

Table 6. Presentation of material parameters of spruce dust samples.

\begin{tabular}{|c|c|c|c|c|}
\hline \multirow{2}{*}{ Parameters } & \multicolumn{4}{|c|}{$5 \mathrm{~mm}$ of Spuce Dust Layer } \\
\hline & WD_Saw & WD_Briq & WD_ExtrD & WD_Grin \\
\hline Lowest temperature $\left({ }^{\circ} \mathrm{C}\right)$ & $X^{*}$ & 360 & 360 & 350 \\
\hline Ignition time (min) & $X^{*}$ & 7 & 11 & 12 \\
\hline
\end{tabular}

${ }^{*} \mathrm{X}-$ not determined.

The dependence of ignition on surface temperature was statistically evaluated by a t-test and a One-Way ANOVA. However, the amount of data obtained did not confirm the significance of the minimum temperature or ignition time on the type of spruce dust sample. The evaluation follows only from the experimentally obtained data (Table 6, Figure 7). From the point of view of the risk of ignition in the settled layer, dust from the grinder is ignited first, then from briquetting and a sample taken from the container. Th ignition temperature range is comparable. The lowest value of the ignition temperature was in the grinder sample and the highest was in the briquettes. From the point of view of the risk of ignition of the settled dust layer, the spruce dust sample emerges from the briquetting as the worst. The sample WD_Briq has a minimum ignition temperature of $360^{\circ} \mathrm{C}$ and a grinding sample of $350^{\circ} \mathrm{C}$, but the ignition time of the sample WD_Briq is $7 \mathrm{~min}$. The sample taken from the grinding (WD_Grin) ignited after $12 \mathrm{~min}$. It is possible to assume a slower heating of the WD-Grin layer (with the smallest particle composition) and therefore there is a delay of ignition (12 $\mathrm{min})$, but at a lower temperature.

Tureková and Marková [53] carried out a hot-plate experiment with samples of spruce, beech and oak dusts. The samples (sawdust) were produced using a circular saw. However, 
spruce samples have the same moistures and a mean sieve analysis value of $250 \mu \mathrm{m}$. Their minimum ignition temperature $\left(300^{\circ} \mathrm{C}\right)$ was lesser than ours.

After ignition, the deposited dust only ends up slowing oxidation reactions, such as decay, heating or low-temperature carbonization. The burning rate of settled dust can range from a slow spread, and can decay to a violent explosion [35].

Horváth and Balog [36] determined the minimum temperature of dusts, from different types of pellets, by isothermal thermal stress of combustible dust on an electrically heated metal plate and continuous measurement of the temperature inside the sample.

The results of individual measurements of the ignition temperature of settled dusts (according to EN 50281-2-1: 2002 [52]) differ (Table 7), as the determined sample density differs in the mentioned experiments. Tureková [68] states the humidity of oak wood dust to be $4.7 \%$, spruce dust to be $4.2 \%$ and DTD dust to be $4.2 \%$.In an experiment from [69], the moisture content of beech dust was $1.002 \%$, and that of oak dust was $0.884 \%$. This was reflected in the lower values of the ignition temperature of the samples.

Table 7. Overview of minimum ignition temperatures of flammable dusts according to EN 50281-2-1 [48].

\begin{tabular}{|c|c|c|c|c|}
\hline \multirow{2}{*}{ Dust } & \multirow{2}{*}{$\begin{array}{l}\text { Layer } \\
(\mathrm{mm})\end{array}$} & \multicolumn{3}{|c|}{$\operatorname{MIT}\left({ }^{\circ} \mathrm{C}\right)$ by } \\
\hline & & [49] & [64] & [36] \\
\hline \multirow{3}{*}{ spruce } & 5 & & 320 & 340 \\
\hline & 12 & & 290 & \\
\hline & 15 & 300 & & \\
\hline
\end{tabular}

The determination of the minimum ignition temperature of dusts in the settled state is described in detail in the paper [69]. They performed measurements for beech dust obtained through various technological methods(carpentry belt grinder and GBS 100 AE). Differences in the ignition temperatures of these samples were not confirmed.

\section{Conclusions}

Based on the performed experiments, it is possible to draw the following conclusions:

- The moisture parameter of individual samples was statistically evaluated and a significant dependence of the type of technological operation on dust moisture was confirmed;

- $\quad$ Spruce wood dust obtained from selected wood processing plants had a different particle size distribution, where it was not possible to statistically confirm due to the difference in the used sieves. Wood dust from sawing has the largest proportion-69\% of the $250 \mu \mathrm{m}$ fraction-and the saw sample (WD_Saw) did not ignite on the hot-plate. Sawdust represents the particle size distribution with the largest proportion of sieve sizes with a cut-off value of $<90 \mu \mathrm{m}$. Grinding, as a fine technological operation, produces the smallest dimensions of dust particles, with the most numerous fraction of $63 \mu \mathrm{m}(87 \%)$;

- The monitoring of the ignition of settled dust samples of spruce (5 mm thickness) obtained through selected technologies on a hot surface was realized. The monitored parameter of the minimum ignition temperature of settled dust $t_{u M I N}$ was identified for WD_Briq, WD_ExtrD and WD_Grin. These values were comparable. However, time of ignition was different. The time of ignition increased with the decrease in the average value of particle size in the samples (Table 3).

- In terms of the risk of initiating a settled dust layer, the spruce dust sample emerges from the briquetting as the worst. Although WD_Briq has a minimum ignition temperature of $360{ }^{\circ} \mathrm{C}$ and a grinding sample of $10^{\circ} \mathrm{C}$, the ignition time of the WD_Briq sample is $7 \mathrm{~min}$. The sample taken from the grinding ignited after $12 \mathrm{~min}$.

Author Contributions: Conceptualization, E.M. and I.M.; methodology, E.M.; software, J.S.; formal analysis, J.J.; investigation, E.M.; resources, E.M.; writing—original draft preparation, I.M. and I.T.; 
writing - review and editing, E.M., I.T. and M.H.; project administration, J.J. and M.H. All authors have read and agreed to the published version of the manuscript.

Funding: This research was funded by grant number K-026UMB-4/2021 Demonstration laboratory of work safety for manual devoices in human-machine interaction.

Institutional Review Board Statement: Not applicable.

Informed Consent Statement: Not applicable.

Data Availability Statement: Not applicable.

Acknowledgments: This article was supported by the Cultural and Education Grant Agency of the Ministry of Education, Science, Research and Sport of the Slovak Republic on the basic of the project No. K-026UMB-4/2021 Demonstration laboratory of work safety for manual devoices in human-machine interaction.

Conflicts of Interest: The authors declare no conflict of interest.

\section{References}

1. Kminiak, R.; Siklienka, M.; Igaz, R.; Krišt’ák, L'.; Gergel', T.; Němec, M.; Réh, R.; Očkajová, A.; Kučerka, M. Effect of cutting conditions on quality of milled surface of medium-density fibreboards. BioRes 2020, 15, 746-766. [CrossRef]

2. Medved, S.; Tudor, E.M.; Barbu, M.C.; Jambrekovic, V.; Spanic, N. Effect of Pine (Pinus Sylvestris) Bark Dust on Particleboard Thickness Swelling and Internal Bond. Drv. Ind. 2019, 70, 141-147. [CrossRef]

3. Bekhta, P.; Noshchenko, G.; Réh, R.; Kristak, L.; Sedliačik, J.; Antov, P.; Mirski, R.; Savov, V. Properties of Eco-Friendly Particleboards Bonded with Lignosulfonate-Urea-Formaldehyde Adhesives. Materials 2021, 14, 4875. [CrossRef] [PubMed]

4. Sydor, M.; Mirski, R.; Stuper-Szablewska, K.; Rogoziński, T. Efficiency of Machine Sanding of Wood. Appl. Sci. 2021, 11, 2860. [CrossRef]

5. Kaczmarzyk, P.; Małozięć, D.; Warguła, Ł. Research on electrical wiring used in the construction of working machines and vehicles in the aspect of fire protection. J. Mech. Transp. Eng. 2018, 70, 13-24.

6. Magagnotti, N.; Nannicini, C.; Sciarra, G.; Spinelli, R.; Volpi, D. Determining the Exposure of Chipper Operators to Inhalable Wood Dust. Ann. Occup. Hyg. 2013, 57, 784-792. [CrossRef]

7. WHO. Hazard Prevention and Control in the Work Environment: Airborne Dust; WHO/SDE/OEH/99.14; World Health Organization: Geneva, Switzerland, 1999.

8. Gulci, S.; Akay, A.E.; Spinelli, R.; Magagnotti, N. Assessing the Exposure of Chipper Operators to Wood Dust in a Roadside Landing Area. Fresenius Environ. Bull. 2018, 27, 4132-4138.

9. Oravec, M.; Pačaiová, H.; Ižaríkov, G.; Hovanec, H. Magnetic Field Image-Source of Information for Action Causality Description. In Proceedings of the 2019 IEEE 17th World Symposium on Applied Machine Intelligence and Informatics (SAMI), Herl'any, Slovakia, 24-26 January 2019; pp. 101-106.

10. Straumfors, A.; Olsen, R.; Daae, H.L.; Afanou, A.; McLean, D.; Corbin, M.; Mannetje, A.T.; Ulvestad, B.; Bakke, B.; Johnsen, H.L.; et al. Exposure to Wood Dust, Microbial Components, and Terpenes in the Norwegian Sawmill Industry. Ann. Work. Expo. Health 2018, 62, 674-688. [CrossRef]

11. Pačaiová, H.; Andrejiová, M.; Balážiková, M.; Tomášková, M.; Gazda, T.; Chomovoá, K.; Hijj, J.; Salaj, L. Methodology for Complex Efficiency Evaluation of Machinery Safety Measures in a Production Organization. Appl. Sci. 2012, 11, 453. [CrossRef]

12. Qian, G.; Duanmu, C.; Ali, N.; Khan, A.; Malik, S.; Yang, Y.; Bilal, M. Hazardous wastes, adverse impacts, and management strategies: A way forward to environmental sustainability. Environ. Dev. Sustain. 2021, 1-26. [CrossRef]

13. Marková, I.; Hroncova, E.; Tomaskin, J.; Tureková, I. Thermal Analysis of Granulometry Selected Wood Dust Particles. BioResources 2018, 13, 8041-8060. [CrossRef]

14. Ballay, M.; Sventeková, E. Use of the Method of Operational Analysis in the Framework of Technological Safety of Emergency Work. Transp. Res. Procedia 2021, 55, 1490-1497. [CrossRef]

15. Zachar, M.; Čabalová, I.; Kačíková, D.; Zacharová, L. The Effect of Heat Flux to the Fire-Technical and Chemical Properties of Spruce Wood (Picea abies L.). Materials 2021, 14, 4989. [CrossRef]

16. Cheremisinoff, N.P. Dust Explosion and Fire Prevention Handbook: A Guide to Good Industry Practices; Scrivener Publishing: Beverly, CA, USA, 2014.

17. Taghiyari, H.; Militz, H.; Antov, P.; Papadopoulos, A. Effects of Wollastonite on Fire Properties of Particleboard Made from Wood and Chicken Feather Fibers. Coatings 2021, 11, 518. [CrossRef]

18. Castells, B.; Amez, I.; Medic, L.; Torrent, J.G. Particle Size Influence on the Transport Classification Labels and Other Flammability Characteristics of Powders. Appl. Sci. 2020, 10, 8601. [CrossRef]

19. Makka, K.; Sventekova, E. Risk Evaluation by Transport of Dangerous Substances. In Proceedings of the 18th International Conference, Transport Means, Kaunas UnivTechnol, Kaunas, Lithuania, 23-24 October 2004; pp. 308-311.

20. Saeed, M.A.; Farooq, M.; Andrews, G.E.; Phylaktou, H.N.; Gibbs, B.M. Ignition sensitivity of different compositional wood pellets and particle size dependence. J. Environ. Manag. 2019, 232, 789-795. [CrossRef] [PubMed] 
21. Pędzik, M.; Stuper-Szablewska, K.; Sydor, M.; Rogoziński, T. Influence of Grit Size and Wood Species on the Granularity of Dust Particles During Sanding. Appl. Sci. 2020, 10, 8165. [CrossRef]

22. Tudor, E.M.; Zwickl, C.; Eichinger, C.; Petutschnigg, A.; Barbu, M.C. Performance of softwood bark comminution technologies for determination of targeted particle size in further upcycling applications. J. Clean. Prod. 2020, 269, 122412. [CrossRef]

23. Dado, M.; Lamperová, A.; Kotek, L.; Hnilica, R. An Evaluation of On-Tool System for Sanding Dust Collection: Pilot Study. Manag. Syst. Prod. Eng. 2020, 28, 184-188. [CrossRef]

24. Vandličková, M.; Marková, I.; Osvaldová, L.M.; Gašpercová, S.; Svetlík, J.; Vraniak, J. Tropical Wood Dusts—Granulometry, Morfology and Ignition Temperature. Appl. Sci. 2020, 10, 7608. [CrossRef]

25. Pędzik, M.; Rogoziński, T.; Majka, J.; Stuper-Szablewska, K.; Antov, P.; Kristak, L.; Kminiak, R.; Kučerka, M. Fine Dust Creation during Hardwood Machine Sanding. Appl. Sci. 2021, 11, 6602. [CrossRef]

26. Dimou, V.; Malesios, C.; Chatzikosti, V. Assessing chainsaw operators' exposure to wood dust during timber harvesting. Appl. Sci. 2020, 2, 1899. [CrossRef]

27. Očkajová, A.; Kučerka, M.; Kminiak, R.; Krišt'ák, L'.; Igaz, R.; Réh, R. Occupational Exposure to Dust Produced when Milling Thermally Modified Wood. Int. J. Environ. Res. Public Health 2020, 17, 1478. [CrossRef] [PubMed]

28. Vandlickova, M.; Markova, I.; Makovicka-Osvaldova, L.; Gaspercova, S.; Svetlik, J. Evaluation of African Padauk (Pterocarpussoyauxii) Explosion Dust. BioResources 2020, 15, 401-414.

29. Yepes, M.E.G.; Cremades, L.V. Characterization of wood dust from furniture by scanning electron microscopy and energydispersive x-ray analysis. Ind. Health 2011, 49, 492-500. [CrossRef] [PubMed]

30. Mazzoli, A.; Favoni, O. Particle size, size distribution and morphological evaluation of airborne dust particles of diverse woodsby Scanning Electron Microscopy and image processing program. Powder Technol. 2012, 225, 65-71. [CrossRef]

31. Papadopoulos, A.N. Advances in Wood Composites II. Polymers 2020, 12, 1552. [CrossRef]

32. Tureková, I.; Marková, I.; Ivanovičová, M.; Harangózo, J. Experimental Study of Oriented Strand Board Ignition by Radiant Heat Fluxes. Polymers 2021, 13, 709. [CrossRef]

33. European Committee for Standardization. EN 2711-1: 2012 Explosive Atmospheres. Explosion Prevention and Protection. Part 1: Basic Concepts and Methodology; European Committee for Standardization: Brussels, Belgium, 2012.

34. Zhi, Y. Dynamic Risk Analysis of Dust Explosions. Ph.D. Thesis, Faculty of Engineering and Applied Science, Memorial University of Newfoundland, St. John's, N.L., Canada, 2015. Available online: https:/ / research.library.mun.ca/11657/1/thesis.pdf (accessed on 30 June 2015).

35. Tureková, I. Risks of industrial wood dust. In Proceedings of the 11th International Symposium, Bratislava, Slovakia, 5-6 December 2008; pp. 167-179. (In Slovak)

36. Horváth, J.; Balog, K. Ignition temperature of settlement and distributed dust from industrially produced wood pellets. In Proceedings of the 13rd International Scientific Conference, Bratislava, Slovakia, 18-19 April 2013; pp. 101-105. (In Slovak)

37. Eckhoff, R.; Li, G. Industrial Dust Explosions. A Brief Review. Appl. Sci. 2021, 11, 1669. [CrossRef]

38. Półka, M.; Salamonowicz, Z.; Wolinski, M.; Kukfisz, B. Experimental Analysis of Minimal Ignition Temperatures of a Dust Layer and Clouds on a Heated Surface of Selected Flammable Dusts. Procedia Eng. 2012, 45, 414-423. [CrossRef]

39. Pastier, M.; Tureková, I.; Turňová, Z.; Harangózo, J. Minimum ignition temperature of wood dust layers. Res. Pap. Fac. Mater. Sci. Technol. Trnava 2013, 21, 121-131. (In Slovak) [CrossRef]

40. Tureková, I. Study of initiating sources of wood dust. Proc. Sci. Work. Tech. Univ. Ostrav. Czech Repub. 2009, 1, 105-116. (In Slovak)

41. Damec, J. Explosion Prevention in Food and Agriculture; SPBI Spektrum: Ostrava, Czech Republic, 1999; p. 252. (In Czech)

42. Eghdami, H.; Werner, W.; Büker, P.; Sicard, P. Assessment of ozone risk to Central European forests: Time series indicates perennial exceedance of ozone critical levels. Environ. Res. 2021, 203, 111798. [CrossRef]

43. Potkany, M.; Hitka, M.; Lorincová, S.; Krajčírová, L.; Starchon, P. Use of Variators in Applying the Cost Calculation Methodology in Small and Medium Furniture Enterprises Based on Changes in Human Body Dimensions. Drv. Ind. 2019, 70, 27-35. [CrossRef]

44. Lorincová, S.; Stachová, K.; Stacho, Z.; Joniaková, Z.; Blštáková, J.; Lipoldová, M.; Hitka, M. Defining the differences in corporate culture in wood-processing and forest enterprises. BioResources 2020, 15, 2839-2849. [CrossRef]

45. Hauglin, M.; Rahlf, J.; Schumacher, J.; Astrup, R.; Breidenbach, J. Large scale mapping of forest attributes using heterogeneous sets of airborne laser scanning and National Forest Inventory data. For. Ecosyst. 2021, 8, 65. [CrossRef]

46. Krišt'ák, L.; Réh, R. Application of Wood Composites. Appl. Sci. 2021, 11, 3479. [CrossRef]

47. Jad'ud'ová, J.; Zeleny, J.; Marková, I.; Tomaškinová, J.; Vicianová, J.H. Stakeholder Management as Part of Integrated Management System in the Furniture Industry. Procedia Econ. Finance 2015, 34, 129-133. [CrossRef]

48. Kačík, F.; Laurová, M.; Kačíková, D. Analytical Chemistry, 1st ed.; Technical University in Zvolen: Zvolen, Slovakia, $2012 ;$ pp. 11-16. (In Slovak)

49. Barański, J.; Suchta, A.; Barańska, S.; Klement, I.; Vilkovská, T.; Vilkovský, P. Wood Moisture-Content Measurement Accuracy of Impregnated and Nonimpregnated Wood. Sensors 2021, 21, 7033. [CrossRef] [PubMed]

50. European Committee for Standardization. EN ISO 1666: 2000 Starch—Determination of Moisture Content-Oven-Drying Method; European Committee for Standardization: Brussels, Belgium, 2000.

51. European Committee for Standardization. ISO 9276-1:1998. Representation of Results of Particle Size Analysis-Part 1: Graphical Representation; International Organization for Standardization: Geneva, Switzerland, 1998. 
52. European Committee for Standardization. EN 50281-2-1: 2002. Electrical Apparatus for Use in the Presence of Combustible Dust. Part 2-1: Test Methods. Methods for Determining the Minimum Ignition Temperatures of Dust; European Committee for Standardization: Brussels, Belgium, 2002.

53. Tureková, I.; Marková, I. Ignition of Deposited Wood Dust Layer by Selected Sources. Appl. Sci. 2020, 10, 5779. [CrossRef]

54. Warguła, Ł.; Dziechciarz, A.; Kaczmarzyk, P. The assessment of fire risk of non-road mobile wood chopping machines. J. Res. Appl. Agric. Eng. 2019, 64, 58-64.

55. Proto, A.R.; Zimbalatti, G.; Negri, M. The measurement and distribution of wood dust. J. Agric. Eng. 2010, 41, 25-31. [CrossRef]

56. Marková, I.; Ladomerský, J.; Hroncová, E.; Mračková, E. Thermal parameters of beech wood dust. BioRes 2018, 13, 3098-3109. [CrossRef]

57. Tureková, I.; Mračková, E.; Marková, I. Determination of Waste Industrial Dust Safety Characteristics. Int. J. Environ. Res. Public Health 2019, 16, 2103. [CrossRef]

58. Ding, T.; Zhao, J.; Zhu, N.; Wang, C. A comparative study of morphological characteristics of medium-density fiberboard dust by sieve and image analyses. J. Wood Sci. 2020, 66, 55. [CrossRef]

59. Kučerka, M. Analysis of sawdust fractions formed during wood sawing processes. Acta Univ. Matthiae Belii. Ser. Tech. Educ. 2014, 2004, 36-43. (In Slovak)

60. Loungaver, J.; Dzurenda, J. Granulometric analysis of dry spruce sawdust extraction into the CLASSIC 150/200 frame saw and the possibility of its efficient separation. In Proceeding of the Chip and Chipless Woodworking Conference, Zvolen, Slovakia, 12-14 October 2006; pp. 185-190.

61. Mračkova, E.; Tsilimigkas, G. Assessment of Microscopy and the Size Fractions of Beech Wood Dust in Connection with Explosions; Sdružení Požárního a Bezpečnostního Inženýrství: Ostrava, Czech Republic, 2017; pp. 63-67. (In Slovak)

62. Marková, I.; Mračková, E.; Očkajová, A.; Ladomerský, J. Granulometry of selected wood dust species of dust from orbital sanders. Wood Res. 2016, 61, 983-992.

63. Očkajová, A.; Marková, I. Particular size analysis of selected wood dust species particles generated in the wood working environment. Acta Univ. Matthiae Belii Ser. Environ. Manag. 2016, 18, $24-31$.

64. Mračková, E.; Krišt'ák, L'; Kučerka, M.; Gaff, M.; Gajtanska, G. Creation of wood dust during wood processing: Size analysis, dust separation, and occupational health. BioRes 2016, 11, 209-222. [CrossRef]

65. Mračková, E.; Oremusová, E. Determination of selected fire-technical characteristics of wood dust. In Proceedings of the 8th International Scientific Wood \& Fire Safety Conference, Žilina, Slovakia, 3 May 2016; EDIS-Publishing Center of the University of Žilina: Žilina, Slovakia, 2016; pp. 221-227.

66. Yuan, Z.; Khakzad, N.; Khan, F.; Amyotte, P. Risk Analysis of Dust Explosion Scenarios Using Bayesian Networks. Risk Anal. 2014, 35, 278-291. [CrossRef]

67. Kminiak, R.; Kucerka, M.; Kristak, L.; Reh, R.; Antov, P.; Ockajová, A.; Rogozinski, T.; Pedzik, M. Granulometric Characterization of Wood Dust Emission from CNC Machining of Natural Wood and Medium Density Fiberboard. Forests 2021, 12, 1039. [CrossRef]

68. Tureková, I.; Slabá, I.; Duchoň, M. Evaluation of dust risks in the work environment. In Proceedings of the 7th International Scientific Conference Health and Safety at Work, Ostrava, Slovakia, 12-13 June 2007; pp. 321-327. (In Slovak)

69. Mračková, E.; Tureková, I. The dimensional characteristics of the particles of wood dust of selected deciduous trees considering to explosion. Key Eng. Mater. 2016, 688, 182-189. [CrossRef] 